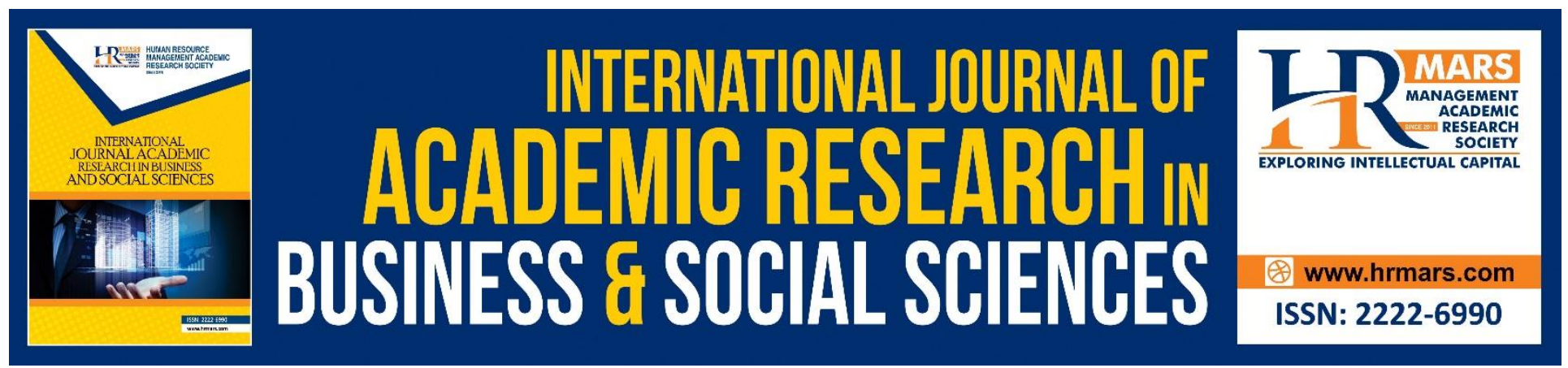

\title{
The Mismanagement of Jus Post Bellum in Achieving Just Peace: The Case of Cambodia
}

Farhatul Mustamirrah, Mohd. Rizal Yaakob

To Link this Article: http://dx.doi.org/10.6007/IJARBSS/v8-i7/4408

DOI: $\quad 10.6007 /$ IJARBSS/v8-i7/4408

Received: 29 May 2018, Revised: 23 June 2018, Accepted: 29 June 2018

Published Online: 18 July 2018

In-Text Citation: (Mustamirrah \& Yaakob, 2018)

To Cite this Article: Mustamirrah, F., \& Yaakob, M. R. (2018). The Mismanagement of Jus Post Bellum in Achieving Just Peace: The Case of Cambodia. International Journal of Academic Research in Business and Social Sciences, 8(7), 648-663.

\section{Copyright: (C) 2018 The Author(s)}

Published by Human Resource Management Academic Research Society (www.hrmars.com)

This article is published under the Creative Commons Attribution (CC BY 4.0) license. Anyone may reproduce, distribute, translate and create derivative works of this article (for both commercial and non-commercial purposes), subject to full attribution to the original publication and authors. The full terms of this license may be seen

at: $\underline{\text { http://creativecommons.org/licences/by/4.0/legalcode }}$

Vol. 8, No. 7, July 2018, Pg. 648 - 663

http://hrmars.com/index.php/pages/detail/IJARBSS

JOURNAL HOMEPAGE

Full Terms \& Conditions of access and use can be found at http://hrmars.com/index.php/pages/detail/publication-ethics 


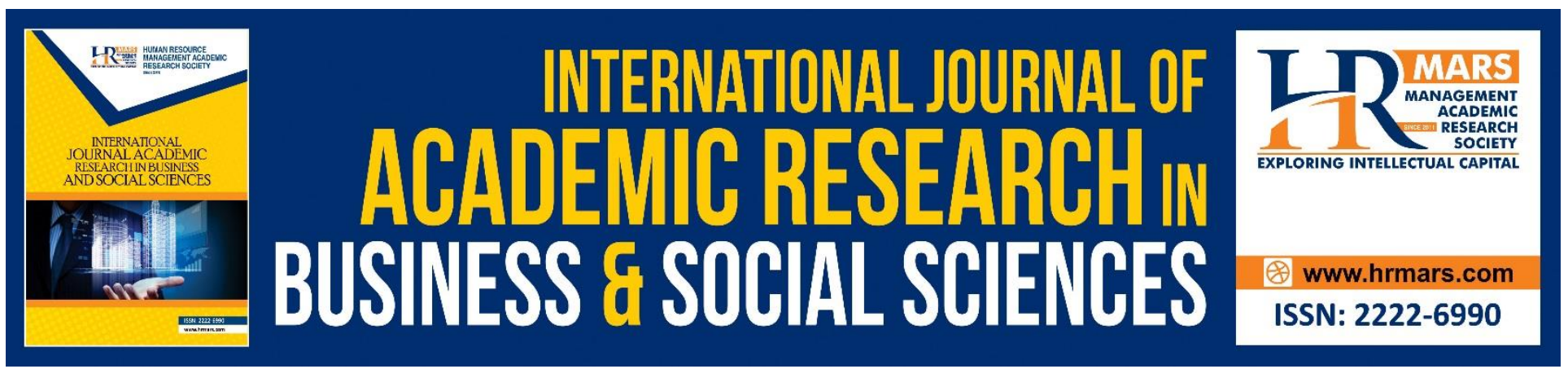

\title{
The Mismanagement of Jus Post Bellum in Achieving Just Peace: The Case of Cambodia
}

\author{
Farhatul Mustamirrah, Mohd. Rizal Yaakob \\ Fakulti Sains Sosial dan Kemanusiaan, Universiti Kebangsaan Malaysia (UKM) \\ Email: nnhasuna@gmail.com
}

\begin{abstract}
War has three phases, the beginning (jus ad bellum), the middle (jus in bello), and the end (jus post bellum). This article discusses the mismanagement of post-conflict justice that is the end of war in achieving just peace which is the objective of jus post bellum. Jus post bellum is a problematic aspect of war in which the law regulating the transition of the state of war to the state of peace was not fully developed at the moment and in most cases it is heavily dependent on an ad hoc committee under the auspices of the United Nations. Cambodia is selected as the case study for this discussion in order to emphasize on the need for a systematic framework for jus post bellum in the international law. Due to the absence of a systematic framework for jus post bellum, just peace in Cambodia was not achieved. This discussion finds out that a systematic framework for post-conflict justice is imminent but without major reforms in certain areas it will be unachievable. These major reforms include, revamping and reducing the veto power of the Security-Council, empowering the Secretary-General and the General Assembly, reforming the International Court of Justice, and empowering more NGOs. Keywords: War, Jus Post Bellum, Just Peace, Post-Conflict Justice, United Nations.
\end{abstract}

\section{Introduction}

The first Indo-China War (1946-1954) was a war of independence, a war in which Cambodia fought against France for deliverance of its status as a protectorate (Cable, 1986). This is where the start of several complicated events starting from civil wars within the state and alongside the borders of Vietnam and Cambodia to genocide that triggers the attention of the UN due to its gross violation of human rights.

In 1982, with the encouragement of the Association of South-East Asian Nations (ASEAN) and support from People's Republic of China and the US, the three Cambodian rebel factions formed the Coalition Government of Democratic Kampuchea (CGDK). The Soviet Union and the People's Republic of China's support and interest was obviously due to the fact that they share the same communist value. However, due to the fact that Vietnam invaded Cambodia, there is an issue of lack of legitimacy on the rule of Vietnam over Cambodia as well as lack in international recognition outside the communist circle. Cambodia under the rule of communist Vietnam was rule according to the model 
INTERNATIONAL JOURNAL OF ACADEMIC RESEARCH IN BUSINESS AND SOCIAL SCIENCES

Vol. 8, No. 7, July 2018, E-ISSN: 2222-6990 @ 2018 HRMARS

of socialist states and applying communist ideology through its constitution. It is reported that no elections were held until 1981, and even those were not contested by opposing parties.

ASEAN supported the rule of Sihanouk and directly assumed the leading role in the opposition to Vietnam rule. United States main cause for the opposition of the rule of Vietnam is to curb any communist movement. Apart from that, the promotion of political stability of the ASEAN states was of interest due to their growing economy. Since Cambodia has become the member of the UN since 1955, it is decided that the legitimate government to represent Cambodia was the Coalition Government of Democratic Kampuchea. Although there was resistance on the legitimacy of the coalition government, majority of states referred to the fact, that the Coalition Government of Democratic Kampuchea exercised effective control over the territory and that the Vietnamese regime derived from a breach of the principle of the prohibition of the use of force as provided for in Article 2 para. 4 of the UN Charter (Ratliff, 1999). Due to this, the Vietnamese refused to involve or vote and refused to recognize the resolutions passed by the General Assembly.

\section{The Un and the Peace Process}

The first international reaction to the Cambodian conflict was in 1978, when the UN considered Cambodia's human rights situation during the period of the Khmer Rouge regime for the first time (Keller, 2005). However, when Vietnam invaded Cambodia on the same year, the UN under its SubCommission merely limited itself to observing the human rights situation.

In January 1979, due to Vietnam's invasion of Cambodia, the UN Security Council reviewed the Cambodian situation by attempting to draft two resolutions, 1) calling on all parties to cease combat, and 2) calling for the withdrawal of all foreign troops, the People's Republic of China and Vietnam's troop, from Cambodia (Keller, 2005; Doc, 1979). No major success in both attempts because for the first resolution, no majority among the members and the second resolution was vetoed by the Soviet Union, for very obvious reason.

When the UN failed to find a peaceful solution for Cambodia, ASEAN member states demanded that the situation in Kampuchea to be included on the agenda of the General Assembly's $34^{\text {th }}$ session (Keller, 2005). As a result, General Assembly adopted Resolution 34/22 calling for the immediate withdrawal of all foreign forces from Cambodia.

From a political perspective, given the situation in the Cold War era characterised by vast dissensions among the aligned states, the fact that the General Assembly drafted Resolution 34/22 helped to approach the Cambodian situation because otherwise, the Soviet Union could keep blocking the process by using its veto power (Nolte, 1995).

Several attempts made by the UN such as holding international conferences to invite actors involve discussing peace implementation process in Cambodia did not achieve its goal. Even the attempt by the ASEAN members to solve the conflict in Cambodia did not achieve its goal due to disagreement between the Cambodian factions. None of the international conferences for peace for Cambodia is successful in achieving a comprehensive settlement until finally Vietnam decided to withdraw its troops and leads to Paris Peace Conference in 1989 (Acharya and Lizee, 1991). The parties directly involved realised that the costs of continuing the conflict were higher than the costs of a political settlement (Keller, 2005).

Despite having some progress towards peace; that is the agreement of conference's participants on the withdrawal of foreign forces, neutralization and the return of refugees; the Paris Conference was to fall far short of providing a decisive breakthrough towards the resolution of the Cambodian conflict (Acharya and Lizee, 1991). The conference failed to find a formula for power 
INTERNATIONAL JOURNAL OF ACADEMIC RESEARCH IN BUSINESS AND SOCIAL SCIENCES Vol. 8, No. 7, July 2018, E-ISSN: 2222-6990 @ 2018 HRMARS

sharing among the four Cambodian factions and the fact that Khmer Rouge participated in the peace process further complicates the issue. The conference thus ended with mapping out a broad strategy for peace but was suspended without achieving a comprehensive settlement (Keller, 2005).

In August 1990, in continuation of the peace effort, the Security Council announce that they had reached a consent on a Framework for a Comprehensive Political Settlement of the Cambodian Conflict, easily known as "Framework Agreement" ( Doc, 1990). The Framework Agreement emphasised at the outset the need for the comprehensive of the future settlement and covers five sections:

“...the transitional arrangements regarding the administration of Cambodia during the preelection period (section 1); the military arrangements during the transitional period (section 2); the elections under United Nations auspices (section 3); human rights protection (section 4); and international guarantees (section 5)". (Framework Agreement, 1990)

The United Nations Transitional Authority in Cambodia (UNTAC) was given a mandate with limited legislative power that included many aspects related to human rights - the organization and conduct of free and fair elections; military arrangements; limited civil administration; the maintenance of law and order; the repatriation and resettlement of Cambodian refugees and internally displaced persons; and the rehabilitation of essential Cambodian infrastructure (Doc, 1991; Res745, 1992).

UNTAC mandate includes civil administration, military functions, provision with regard to the elections and human rights. However, one of the limitations of UNTAC is that it will have only 18 months before the agreement expires. Other limitation of the power of UNTAC is that SNC has the upper hand in terms of how to implement the agreement. Article 6 states that the SNC delegates all powers necessary to the UN in order to ensure the implementation of the agreement (Keller, 2005). Since Sihanouk closely cooperated with UNTAC and the Special Representative, the relationship between the SNC and UNTAC did not cause difficulties thus in general UNTAC's powers were not significantly limited (Keller, 2005).

The establishment of civil administration is one of UNTAC's mandates in Cambodia which involves the installation of a democratically elected government. The agreement provides for a threetiered system to determine the relationship between UNTAC and the current governmental structures that is the large administrative apparatus of the Vietnam faction and the smaller organs of the three Cambodian factions (Ratner, 1993). According to the agreement, on the first tier of the civil administration, "all administrative agencies, bodies and offices acting in the field of foreign affairs, national defence, finance, public security and information will be placed under the direct control of UNTAC". The condition is so to ensure neutral political environment that would be conducive to free and fair elections. However, in order to create and maintain a normal day to day life in Cambodia, the Secretary-General is still to comply with the SNC's advice provided that there is consent among the members and provided that the advice is consistent with the objectives of the agreement.

On July 1992, UNTAC began to exercise its direct control over the state of Cambodia's administration in Phnom Penh (Keller, 2005). At the same time, UNTAC established provincial offices in all Cambodian provinces. With respect to UNTAC's direct control over the administrative entities of all factions, it must be emphasised that in practice only the Vietnamese faction had real administrative structures to control (Keller, 2005). The Front Uni National Pour Un Cambodge Independent, Neutre, Pacifique, et Cooperatif (FUNCINPEC) and the Khmer People's National Liberation Front (KPNLF) had virtually none, while the Khmer Rouge refused to allow UNTAC access to its zones to determine the extent of its administrative control (Findlay, 1995). Despite few 
INTERNATIONAL JOURNAL OF ACADEMIC RESEARCH IN BUSINESS AND SOCIAL SCIENCES Vol. 8, No. 7, July 2018, E-ISSN: 2222-6990 @ 2018 HRMARS

obstacles, the shared power relationship between UNTAC and the SNC provided for the acceptability of the transitional authority's administrative powers.

UNTAC's military function was to stabilise the peace and security situation in Cambodia and to build an environment conducive to free and fair elections (Keller, 2005). UNTAC has a very significant role to ensure that there will be no hostilities that will disrupt the peace process during transitional period. It is without doubt a very fragile situation for a state like Cambodia that has undergone situations like invasions and genocides.

The terror of the Democratic Kampuchea regime necessitated the inclusion of detailed sections on human rights in the Paris Agreement (Ratner, 1993). The peace plan states that:

“...the constitution will contain a declaration of fundamental rights, including the rights to life, personal liberty, security, and freedom of movement, freedom of religion, assembly and association." (Keller, 2005)

The peace plan also includes provision for the rights of people to form political parties and trade unions, due process and equality before the law, protection from arbitrary deprivation of property or deprivation of private property without just compensation, and freedom from racial, ethnic, religious or sexual discrimination.

The detail of human rights provision within the peace plan is not without reason. During the Khmer Rouge regime, each and every right within the peace plan is non-existence, if its existed within the realm then the Khmer Rouge has broke each and every one of the rights. There was literally no constitution of law or judicial process during the regime. The regime planned and executed genocide in mass movements, which includes genocide against religious groups, genocide against ethnic groups and genocide against the majority national group. It is reported that during the 4 years of Pol Pot regime, form 1975-1979, approximately more than 2 million people perished as the result of planned genocide (Kiernan, 2008). The ideology of genocide is of Stalinist and Maoist models, an underlying theme of the political worldview of the Pol Pot group was a concern for national and racial grandiosity (Kiernan, 2008).

The Paris agreement accorded UNTAC the responsibility for promoting an environment during the transitional period, in which respect for human rights was ensured (Comprehensive Agreement, 1991). To fulfil its tasks, UNTAC was active on two main fronts: addressing continuing violations of human rights, particularly those affecting the elections and building the foundations for long term human rights protection (Keller, 2005). In monitoring ongoing violations, UNTAC cooperated closely with the Cambodian authorities, such as to survey prisons throughout the country and to survey the information presented in the media and in education through schools and universities.

The transitional arrangements regarding the administration of Cambodia during the preelection period aim at restoring and maintaining peace in Cambodia, the promotion of national reconciliation and at the realisation of national self-determination through free and fair general elections (Keller, 2005).

According to the Framework Agreement which later being reinforced in the Comprehensive Settlement Agreement of 1991, the Supreme National Council (SNC) forms the exclusive sovereign body representing Cambodia during the transitional period. The SNC, which consists of the four Cambodian factions including the Khmer Rouge, was supposed to support the holding of free and fair elections organised and conducted by the UN during the transitional period.

Elections and the right to vote under the Comprehensive Settlement Agreement, is given to the people. This is in line with the spirit of free and fair election stated in the agreement. UNTAC was the one to determine the exact time for the electoral process, which as per agreement, should not 
INTERNATIONAL JOURNAL OF ACADEMIC RESEARCH IN BUSINESS AND SOCIAL SCIENCES Vol. 8, No. 7, July 2018, E-ISSN: 2222-6990 @ 2018 HRMARS

exceed nine months. UNTAC was also given the responsibility to create a system of voter registration, and to facilitate the presence of foreign election observers (Comprehensive Settlement Agreement, 1991).

The registration of the parties began in August 1992, and voter registration started in October 1992 (Keller, 2005). A total of more than four and a half million Cambodians were registered, representing nearly all estimated potential voters in zones to which UNTAC had access (Marks, 1994). The election, the first after Khmer Rouge regime, took place from 23 to 28 May 1993 in a non-violent environment with the voter turnout constituted a democratically satisfactory result of 90 per cent (Keller, 2005). Later in June 1993, the votes were counted and the result as follows:

"Sihanouk's FUNCINPEC obtained the majority of votes (45 per cent) and hence, the majority of seats in the constituent assembly. The Vietnamese faction achieved 38 percent of the popular vote and the KPNLF not quite four per cent." (Doyle, 1995)

In September 1993, Sihanouk as the head of state signed the new constitution and accepted his formal restoration as King of Cambodia (Keller, 2005). This event marks the end of 18 month mandate of UNTAC.

Now it is without doubt the UNTAC under the UN has transformed the previous communist Cambodia with the worst gross of human rights violation into democratic country that care for human rights which involved the complete transformation of civil administration, reform of constitution and returning the state to liveable environment for the people. However can we consider it as a success story due to the missing element of justice?

The UN Secretary-General, at the outset of UNTAC's mission had identified four essential conditions for it in order to "discharge its responsibilities effectively and with complete impartiality" (Doc, 1992):

"...the full support of the UN of the UN Security Council; the full cooperation of the Cambodian parties and all other parties involved; full freedom of movement and communications; and the necessary financial resources provided by member states in a full and timely manner."

(Findlay, 1995)

These four conditions however were not entirely achieved. As emphasised before, UNTAC under the UN has indeed transform Cambodia into a liveable state for its people. One aspect that is missing is to bring Khmer Rouge to comply with the peace accords and its refusal to participate in the peace process (Findlay, 1995). Because of this matter, post-conflict justice in Cambodia is distorted.

Following the genocidal Pol Pot regime that controlled Cambodia from 1975-1978, there were no significant or effective official public processes of acknowledgment, apology or legal justice implemented in Cambodia, despite the numerous initiatives proposed by the international community and Cambodian government, nor were there any official international acts if condemnation or prosecution (Lambourne, 2004; Etcheson, 1997). During peace negotiations, the Hun Sen government apparently stressed the issue of genocide and the need to bring the perpetrators to justice, but the United States and China supported the Khmer Rouge in blocking any moves in this direction (Lambourne, 2004).

Dissatisfaction arises when Khmer Rouge, the former terror regime, participated in the peace process but denied any UNTAC participation within its territory. The final peace agreement did not preclude the Khmer Rouge from participating in the Cambodian elections, nor did it prevent former officials of the Khmer Rouge associated with the genocide from holding office in the future (Lambourne, 2004). In the name of national reconciliation, the Hun Sen government even accepted the former Khmer Rouge and, in some cases, offered them immunity from prosecution. One of the 
INTERNATIONAL JOURNAL OF ACADEMIC RESEARCH IN BUSINESS AND SOCIAL SCIENCES Vol. 8, No. 7, July 2018, E-ISSN: 2222-6990 @ 2018 HRMARS

most important and difficult challenges confronting a post-conflict society is the re-establishment of faith in the state (Chesterman, 2004). It is a great challenge, especially with the history of violent of the Khmer Rouge regime, whether to give priority over peace or justice in order to balance reconciliation and stability.

The missing part of the UNTAC mandate, that is to bring the genocide criminals to justice, however should be addressed. The key arguments behind holding such trials to bring about justice for the victims are multifaceted: Firstly, only when the person's suffering is acknowledged, and by sentencing the guilty, the innocent would be acquitted. However, with the authorities, that is the UN and the Hun Sen government, abstaining themselves from taking the lead in these trials, it could be interpreted as if the authorities indirectly sanction the crimes committed (Ojendal, 2003). Secondly, the failure to hold such trials has instilled a 'culture impunity' in Cambodia and if genocide can be done without retribution, then anything can pass (Marks, 1994). Thirdly, if the 'books are not closed', it could at any time be taken as a pretext for exercising violence.

Given the dimension of the crimes committed by the Khmer Rouge during the Pol Pot regime, the fact that the Cambodia is a party to the Genocide Convention and the degree of international involvement in the comprehensive state building process would lead to the assumption that the Paris Agreement or - at any rate - the Cambodian institution would address the issue of post-conflict justice (Marks, 1994).

Thus it can be said that just peace in post-conflict Cambodia was not achieved. Justice in just peace in the context of post-conflict settings is incurring what one deserves and it implies that those who had responsibility for political and military choices that violated basic principles of humanity and/or the laws of armed conflict are accountable for their decisions and their deeds. The last active Khmer Rouge leaders surrendered only in 1999, thus Khmer Rouge as a fighting force still existed for 20 years after the official end of the regime (Keller, 2005). Upholding those who are responsible for the gross violation of human rights should be the essence of any peace plan in order to prevent vengeful individuals that can sow the seeds of future war. Some may argue that peace process is a very fragile situation, in which it is balance between peace and conflict thus one should not undermine the ability of belligerents to negotiate in good faith. However, a situation of post-conflict without punishment for wrongdoers defeats the purpose of reconciliation altogether when those responsible for injustice and violence retain their posts of authority like of the case of the Khmer Rouge leaders who are being absorbed to serve within the civil administration.

Reconciliation brings about emotional healing to the victims of war. Reconciliation in the jus post bellum essence, that is the post-conflict justice, is not as simple as "forgive and forget" whereas its richer understanding of reconciliation demands acknowledgement of guilt, reparations (penance), and only then absolution. Admission of guilt are not the same as admissions of criminal activity, which must be punished, thus mutual admissions of guilt are a necessary first step for long term healing process of reconciliation (Allman and Winright, 2007). Prime Minister Hun Sen of Cambodia has promoted a policy of 'national reconciliation' which effectively means a policy of compromise and accommodation rather than the truth, acknowledgement and accountability sought by Cambodian survivors (Lambourne, 2004). It should be mentioned that Hun Sen was part of the army that invaded Cambodia and less repressive regime was established with Hun Sen, first as Foreign Minister, and then as Prime Minister from 1985 onwards. It is very predictable if his policy of national reconciliation aims at avoiding the truth, acknowledgement of crimes and avoids to be held accountable for 'past crimes'. 
INTERNATIONAL JOURNAL OF ACADEMIC RESEARCH IN BUSINESS AND SOCIAL SCIENCES Vol. 8, No. 7, July 2018, E-ISSN: 2222-6990 @ 2018 HRMARS

Many of the political, military and financial elites in Cambodia were affiliated with former Khmer Rouge officials (Keller, 2005). Although public opinion surveys discovered repeatedly that the overwhelming majority of Cambodians wanted the Khmer Rouge leadership to be prosecuted for their crimes, thus far the political elite has been unwilling to do so, because nobody has completely clean hands (Etcheson, 2004). This is the first mistake of the peace plan of Cambodia, which is the inclusion of the Khmer Rouge leaders-despite their uncooperative and resistance nature-in the long term peace plan of Cambodia. They should be held liable for their actions-and their refusal to cooperate in good faith-from day one.

Next element missing in the long term peace plan of Cambodia is the punishment clause. It is well known fact that the issue of post-conflict justice in Cambodia came seriously to the fore only in late 2003. The international community's interest in accountability for Khmer Rouge crimes has increased only in recent years. This is due to the fact that from 1979 until 1989, international commitment predominantly focussed on the Vietnamese troops' withdrawal from Cambodia. Only subsequent to Vietnam's withdrawal in 1989 , did the issue of post-conflict justice come to the fore.

Under jus post bellum, the punishment primary objectives are justice, accountability, and restitution. The legitimacy of punishment depends on publicity and transparency, proportionality and discrimination and competent authority to fulfil two principal parts of punishment: compensation and war crime trials (Allman and Winright, 2007). There is no part in the Paris Agreement that stated on the matter of compensation to the victims of genocide by the Khmer Rouge leaders, simply because they were never being treated as criminals at the first place. War crime trials are an essential and longstanding component to postwar justice but it the case of Cambodia, the prosecution of the Khmer Rouge leaders was delayed in the name of Cambodian unity. In the end, even though peace is there, the people of Cambodia are still under suppression to express their rights.

In 1997, the UN and the Cambodian government entered into negotiation on the establishment of a tribunal which resulted in the establishment of Extraordinary Chambers aiming at the prosecution of the Khmer Rouge crimes. The Extraordinary Chambers significantly differ from other war crimes tribunals in place. Extraordinary Chambers are established by a bilateral agreement and established within a domestic legal system. Unlike other war crimes tribunals, international judges are not in the majority on the benches of the chambers (Keller, 2005). One of the Extraordinary Chambers consists of three national and two international judges, the Appeals Chamber consists of four national and three international judges.

The Cambodian law seems to be unelaborated and incomplete (Keller, 2005). The General Assembly resolution calls for negotiations to resume based on a law passed by the Cambodian National Assembly in 2001, which has serious shortcomings from a human rights perspective. The law establishes a special "mixed tribunal" presided over by a majority of Cambodian judges and coprosecutors, along with judges and prosecutors from other countries (Human Rights Watch, 2002).

Cambodian human rights groups and the Cambodian Bar Association have consistently called for trials that meet international standards. On December 9, the Cambodian Human Rights action Committee called on the Cambodian government to "fulfil its obligations to find justice for the dead by accepting international standards of justice.

Thirty years after the fall of Khmer Rouge, Cambodia's culture of impunity remains as strong as ever (Human Rights Watch, 2009). Under Prime Minister Hun Sen, the Cambodian government continues to obstruct the United Nations-supported court created to try senior Khmer Rouge leaders and others most responsible for the deaths of up to 2 million people during the Khmer Rouge-era. Despite more than three years of operations and the expenditure of approximately US\$50 million, 
INTERNATIONAL JOURNAL OF ACADEMIC RESEARCH IN BUSINESS AND SOCIAL SCIENCES Vol. 8, No. 7, July 2018, E-ISSN: 2222-6990 @ 2018 HRMARS

the UN-backed Extraordinary Chambers of the Courts of Cambodia established to hold the Khmer Rouge accountable have held no trials (Human Rights Watch, 2009).

"This is no accident. For more than a decade, China and the United States blocked efforts at accountability, and for the past decade Hun Sen has done his best to thwart justice." (Human Rights Watch, 2009)

In this case, Cambodian government keep pushing the matter of national reconciliation and indirectly signalling that by insisting on the trials, Cambodia will be threatened by instability and chaos.

The UN's readiness for compromise faced with the position of the Cambodian government regarding post-conflict justice regulation has resulted in an inconclusive result.

"The initial disagreement between the two parties was fundamental: the Cambodian government wanted a national tribunal dominated by Cambodia and with assistance of the UN. The UN was only willing to support and assist a predominantly international tribunal because of the dubious reputation of the domestic judiciary." (Etcheson, 1997)

An obvious motivation for the UN to advance the negotiations and to accept compromises with regard to the Extraordinary Chambers may have been the fact that, with many defendants being older than 70, time is running out for justice to be served (Keller, 2005).

\section{Analysis}

UN non intervention after Cambodian independence due to France refusal to involve the UN in its long term peace plan had made Cambodia vulnerable to more conflicts. The era before the UN intervention due to its gross violation of human rights was marked with corruption, failing of political and economic system, civil wars, invasion of Vietnam and planned genocides. These events lead to difficulties to even begin the Cambodian peace process.

The biggest mistake of the international community and the UN was letting Cambodia to determine its own course after 90 years (1863-1953) of colonisation by the French. The difficulties at the early effort of peace process were also due to the entanglement between political and ideological interests of powerful states such as Soviet Union, China and the United States. This situation necessitates a more proper and detailed development of the principles of jus post bellum with the emphasis on just peace under the UN auspices.

The Paris Agreement of 1991 with UNTAC carrying out its mandate of state building can be considered a success. However, UNTAC's role was not without challenge. It is an ambitious attempt to end a decades-old conflict rooted in the events within and outside of Cambodia. If the state building by UNTAC is successful, the same cannot be said about the post-conflict justice settlement in Cambodia. The Khmer Rouge tribunal took too long to established and the fact that the lack credibility and underdeveloped legal system of Cambodia further slowing and hindering the process of justice.

The people of Cambodia has undergone decades of invasion, political instability, economic embargo, civil wars and genocides but none of these 'crimes' has been properly tried and punished. A functional tribunal, by both the UN and Cambodian government, will at least offer some hope of retributive justice and heal the sorrow and trauma still suffered by the people of Cambodia. Pol Pot and his regime should be tried and held in the justice tribunal for the atrocities done towards the people. However, the total opposite happened. The so called national reconciliation by Hun Sen is without doubt to hinder the function of the tribunal. He indirectly asked the people to compromise the crimes and treated it as something of the past. Pol Pot was never tried until his death and most 
INTERNATIONAL JOURNAL OF ACADEMIC RESEARCH IN BUSINESS AND SOCIAL SCIENCES Vol. 8, No. 7, July 2018, E-ISSN: 2222-6990 @ 2018 HRMARS

leaders of the regime is now part of Hun Sen's government. Legal justice was clearly not considered as an important part of peacebuilding process.

Yes the system has changed, with the application of democracy and open market economy, but the regime is still there ruling the nation. It is like the people are now being suppressed by more 'universally acceptable' system. The failure to pursue accountability for human rights violation perpetrated by the Khmer Rouge has not only failed to meet the legal justice need of ordinary people of Cambodia but also created a culture of impunity in Cambodia. Clearly, just peace was not achieved.

\section{Call for Reform}

\section{Revamping the Security Council}

The establishment of the United Nations is mainly to maintain the security and stability of the international system. However, concerns have been expressed regarding its rigidity in handling the matters of the warfare. These concerns are especially directed towards the UN Security Council. The Security Council which consisted of five powerful nations, China, France, Russia, United Kingdom and United States with permanent seats and veto in the council has been widely criticised as obsolete and outdated. Warfare has been changing rapidly and the UN especially its main body should adapt and cope with the change instead of having no unanimity on areas such as post-conflict management. No common strategy has ever been achieved by the council in order to make peace.

There is a serious need to revamp the UN Security Council. It is important to note that the members of the council are nations driven by their national interest that will change according to their nation's policy. Take the example of Cambodia that has been discussed before when French refused the involvement of UN in the post conflict management of Cambodia that has resulted in relapses of events of conflicts that deteriorated the chance to rebuild back the nation. Not after more than 20 years later that the UN started to react to the situation in Cambodia witnessing gross violations of human rights under several regimes after its independence. But the situation has deteriorated so much that several attempts of peaceful resolutions by the UN failed to achieve its objectives. The situation in Cambodia was so complex with disagreement between various factions within Cambodia as well as from outside Cambodia when the Soviet Union kept blocking the peace process by using its veto power.

Empowering the Secretary General and the General Assembly

The 1992 Agenda of Peace by Boutros Boutros Ghali proposed some new ideas on reform on the area of peace making and peace enforcement with the claim that the absence of war after the Cold War period does not in itself ensure the international peace and security. Part of the proposal of the Agenda of Peace is to locate more power under the Secretary General that can act independently in a situation of imminent threat that needed interventions. The current system that has contributed to a lot of critics is if the members of the Security Council veto any decision even the Secretary General is incapable of doing anything. The United States as one of the members of Security Council in many occasion opposed to the creation of special peace enforcement units put at the disposal of the Secretary General. Other important proposal of the Agenda of Peace is advocates a more active used of preventive diplomacy by the UN. Since the UN has been actively involved in peace keeping operations around the world, it should be balanced out with the increase in peace making activities. By advocating peace-making activities, the UN can be directly identify the source of the problems from its grassroots and prevent it from escalating into war. 
INTERNATIONAL JOURNAL OF ACADEMIC RESEARCH IN BUSINESS AND SOCIAL SCIENCES Vol. 8, No. 7, July 2018, E-ISSN: 2222-6990 @ 2018 HRMARS

Peacemaking and peacebuilding should be given a separate enforcement units with a certain degree of autonomy under the order of the Secretary General. The reason for making peacemaking and peacebuilding to be separated under direct authority of the Secretary General is that the UN is known to be heavily burdened with red tape process and layers of chains of commands and if peacebuilding and peacemaking is not separated from such hassle the UN will always be pictured as inefficient and unreliable because of its inability to deploy quickly. Take for example the procedures for increasing the membership of the Security Council; the procedures for reform according to the Articles 108 and 109 of the UN Charter which requires a majority vote of two thirds of the member states including all five permanent members of the Security Council. Such example is a good proof that shows the difficulty involved if peacemaking and peacebuilding is not be given a separate enforcement units. There are numerous articles written on the difficulties encountered by the peacekeeping operations under the UN and their subsequent failures due to unanimity and fragmentations within the UN itself on how to handle the peacekeeping operations.

Post-conflict justice is often left as an afterthought with poor management of state-building by the UN. It usually an ad hoc resolution since there is no systematic rule of law on how to handle justice after the war. Take the example of Cambodia on how the UNTAC has failed to bring forward the war criminals to be tried for their gross violations of human rights. This failure has two folds; first is that the UN has no systematic rule of law for jus post bellum and second is that ICJ as a judiciary organ of the UN is limited in its authority.

The concept of justice in jus post bellum is very crucial because justice in the context of postconflict settings is incurring what one deserved. In this context it refers to the victims of war. Victims are those who have been wronged, whose rights have been violated and had to suffer throughout the war. By punishing those responsible by the rules of law it will give the sense of reconciliation for the victims of war and directly will reinforce political and moral order. Again the case of Cambodia provides an excellent example of what happened if reconciliation was never achieved thus there is no sense of justice and peace. Those responsible for the gross violations of human rights that were the Khmer Rouge regime leaders were never tried for their crimes but instead the culture of impunity is prevailed. There was never a punishment clause under the intervention of UNTAC in the first place. Many attempts to bring those leaders to justice failed and many of those leaders was even be given seats in the government despite them being war criminals. Cambodia until now is still facing numerous charges of human rights violations under the pretence of enforced peace and culture of impunity without any sense of reconciliation and justice for the victims. Justice is an essential ingredient in achieving reconciliation and breaking the cycle of violence. There is no more war, but there is no peace since the people are living in fear of prosecution. Systematic legal framework or law of jus post bellum will help to overcome the need for any ad hoc resolutions that are unsystematic and ineffective.

Illustrations 1: Reform to accommodate Jus Post bellum and achieve Post-conflict justice. 


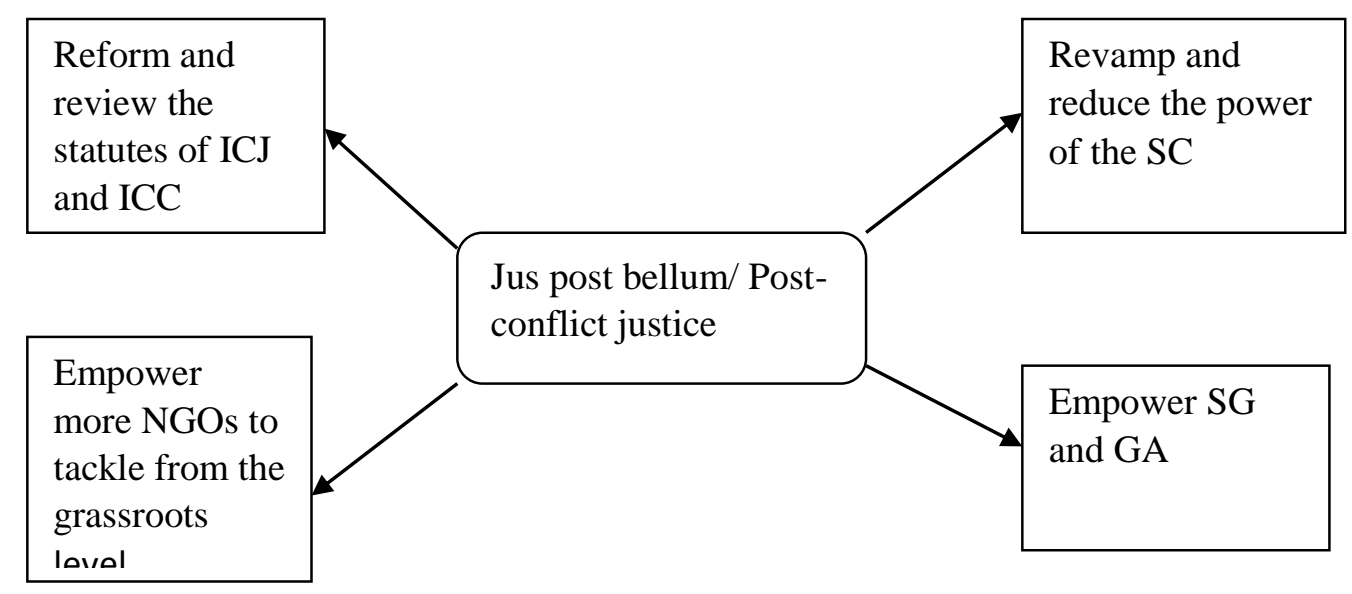

Empowering and reforming the ICC and the ICJ

Such systematic legal framework for jus post bellum should be supported with an effective legal system focusing on the existing international judiciary organ, which is the International Court of Justice (ICJ). ICJ replaced the original League of Nations' permanent Court of International Justice but with no major change in its statutes and jurisdictions. ICJ is the principal judicial organ of the UN that solves inter-state disputes. However there have been many debates that question the effectiveness of such outdated statute of the ICJ that continues without major change from its predecessor the Permanent Court of International Justice of 1920. Is it an effective agency for world peace? The present formal justice system is generally weak, and even with international aid and personnel, has the capacity to handle only relatively small number cases.

Since it is known that the ICJ's jurisdiction is limited, thus its effectiveness and the purpose of ICJ should be questioned. ICJ is limited to cases which the parties to a dispute are willing to bring before it. As can be viewed from the ICJ website, most cases submitted by state parties are those cases that most states are willing to lose and have no significant effect in upgrading the image of ICJ. The number of disputes resolved by the court also remains depressingly small. This is a major hindrance to a more effective and reliable way of ICJ in handling international cases. One of the solutions proposed here is to revise the 1920 original statue of "optional compulsory jurisdiction". The court is not only depends on the willingness of states to bring the case forward but the states should also declare to accept court's jurisdiction if not they are free to reject it. This is the reason why there were no significant jurisdictions since its establishment. The court works as only as an advisory committee with no significant impact though it carries international status in its name.

It has now become clear why most war criminals were not tried since the court has no legal authority whatsoever. It defeats the purpose of its existence that is to produce peaceful resolutions of inter-state disputes in accordance with the law. The outdated statute of the ICJ should be revised and change should take place. The rule of law requires a system of criminal justice that not only punishes but deters any acts of violence. The ICJ should have jurisdictions on all cases that involved inter-states dimensions. International conflicts between states should automatically be submitted to 
INTERNATIONAL JOURNAL OF ACADEMIC RESEARCH IN BUSINESS AND SOCIAL SCIENCES Vol. 8, No. 7, July 2018, E-ISSN: 2222-6990 @ 2018 HRMARS

the ICJ through the tribunals or any ad hoc tribunals. Such international conflicts that violates international law includes, the crimes of gross violation of human rights that violates the Universal Declaration of Human Rights, the crimes if jus ad bellum; conspiring to unjustly attack another state unjustly, the crimes of jus in bello; crimes done during the war such as genocide, rapes, slavery, killing of non combatants civilians, and crimes of jus post bellum; that is reparation and restitution for the victims of war and the trials of the war criminals. The ICJ should have international judge and international lawyers from each nation to maintain neutrality and such positions should not be permanent to avoid the culture of the Security Council discussed above. ICJ as an international judiciary organ should not only have recommendatory effect but link together with domestic judicial organs to punish war criminals and set precedents for future cases.

It is the right time to empower ICJ with so many uprisings of conflicts and violence all around the world. ICJ should be an independent legal entity under the direct supervision of the Security Council and the General Assembly. ICJ also should be equipped with its own enforcement body that will change the nature of its jurisdictions from recommendatory effect to having a legally binding effect. ICJ should be the medium to uphold justice and as protector of the international community. ICJ is part of important components of post-conflict justice in order to provide reconciliations to the victims. The current trend of interconnectedness has already outcome such an outdated statute of 1920 a long time ago. Because of this vacuum of effective law enforcement, post-conflict settings provides a fertile ground for the growth of transnational criminal operations, like we have witnessed in the recent years.

Since the development of International Criminal Court (ICC) is rather new, which formally established in 2002, it is rather not fair to say that the ICC is inefficient. ICC is established in order to overcome the shortcomings of the ICJ. However even the ICC has its own limitations. ICC has jurisdictions on certain type of crime that is war crimes, crimes against humanity and genocide. It is important to note that such jurisdictions are only applicable to members and the non-members include the US, Israel, China and several middle-eastern nations. Under the ICC, there are two types of punishment, imprisonment and compensation. There is one crime that has not yet been given any jurisdictions under the ICJ or even the new ICC, which is the crime of aggression. Crime of aggression refers to any person who plan, fund and instigate aggression and violence. Such law if ever existed and applied will be a greater deterrence against any plan of violence.

Such law on crime of aggression will contribute to the process of reconciliation, to give example in the case of Cambodia. Instead of allowing the culture of impunity to prevail and letting the criminals of war to be part of peace settlement process in order to so-called maintain order and avoiding greater chaos, these criminals who planned and instigated the war should be punished. However, the reality is the one caught is the one who carried out the offence but not included the one who instigate the violence.

The ICC, per its purpose that is to overcome the shortcomings of the ICJ is yet to prove its worth in dealing with the weaknesses of the application of International Law as a whole. Not to mention that those non-members nations that rejected the ICC are those superpowers, namely the US, China and Israel. It has directly defeated the purpose of the ICC altogether. The ICC should be given greater jurisdiction over all nations who violates its laws, members or not, in order for it to be deemed as efficient. It should serve its purpose that is to overcome the shortcomings of the ICJ. 
INTERNATIONAL JOURNAL OF ACADEMIC RESEARCH IN BUSINESS AND SOCIAL SCIENCES Vol. 8, No. 7, July 2018, E-ISSN: 2222-6990 @ 2018 HRMARS

\section{Empowering more NGOs}

One of the problems of the existing UN peacebuilding is that in most of its operation, the agencies under the UN focused mostly on the cooperation with the government while neglecting the roles and demands of community-based organization in their developmental program. This resulted in a biased plan for the provision of infrastructure and lead to more dissatisfaction. Another problem is the structural limitations of the UN peacebuilding commission to involve in a long-term sustainability of a peace plan. There is one way to overcome such problems that is by empowering more nongovernmental organizations (NGOs) as part of peace building's formal commission

The presence of NGOs in their indirect effort of peacebuilding within conflict areas has been increasing over the years with their various activities. NGO in a simple understanding is a non-profit organization working for public good in various areas which includes health, women and children, religion, education, human rights watch, environmental relief and many more. Because most of the NGOs are involved in works relating to development, relief and advocacy, which are of direct and visible benefit to the people, they have achieved a high degree of good will. NGOs work in the center of the conflicts and they reach and indirectly connect to the people. NGOs constitute an essential part of civil society and they have the potential to play key roles in resolving conflicts and restoring civil society from the bottom up. One of the oldest NGOs that have been involving the area of warfare and has been recognized under the Geneva Conventions directly is the International Committee of the Red Cross (ICRC).

NGOs roles in peacebuilding effort have been recognized by the UN but NGOs should be empowered for a more participation especially from the grassroots level in order to overcome the weaknesses of UN peacebuilding stated above. NGOs should be recognized as part of an essential element of peacebuilding and long term peace plan. NGOs can work together with local organizations to fulfil UN's long term peace plan instead of UN replacing the local initiatives and the peace plan crumbles when UN leaves. It is important to put NGOs checked under UN's peacebuilding commission so that their activity can be closely monitored and not jeopardizing the long term peace plan. Their role on behalf of the UN should includes monitoring human rights abuse, intermediating and reporting early warning of potentially violent conflicts and education of future generations in order to create an independent and civilized society. By preserving their own identity and neutrality NGOs appear to be impartial thus providing it more access to conflicting parties, which helps in the process of negotiation. The long term commitment of NGOs is a crucial factor in establishing trust among the people and to attend to the goal of lasting peace.

\section{Conclusion}

All the reforms and changes that have been discussed should sooner or later take place in order to fulfil the gap and weaknesses of peacebuilding and peacemaking so that the cycle of violence can be stopped through just management of post-conflict reconstruction. It has been proven that the current system of peacebuilding and peacemaking has failed to bring forward the intended end of any long-term peace plan that is just peace. It is also important to note that the failure in peacemaking, that is to maintain peace and security of the international system, is partly because of the weakness of the international law to identify the sources of conflicts before it escalated into war and violence. It is urgent to review the outdated system and law of the international law that can cope and adapt with the current trend of the international system. The laws of war, that is the law of occupation and the international humanitarian law, have failed to limit and guide war. The law for 
INTERNATIONAL JOURNAL OF ACADEMIC RESEARCH IN BUSINESS AND SOCIAL SCIENCES Vol. 8, No. 7, July 2018, E-ISSN: 2222-6990 @ 2018 HRMARS

post-conflict justice, or jus post bellum, together with the changes and reforms suggested has becoming more imperative that ever in order to fulfil the gap of peacemaking and peacebuilding.

\section{Acknowledgement}

This work is not funded by any organization. This paper is the result of thesis analysis by the first author and supervised by the second author.

\section{References}

Acharya, A., Lizee, P., and Sorpong P. (1991). Cambodia - The 1989 Paris Peace Conference: Background Analysis and Documents. New York: Kraus International Publications.

Agreement on the Comprehensive Political Settlement of the Cambodia Conflict. (1990). Doc. A/45/472-S/21689 of 31 August 1990.

Agreement on the Comprehensive Political Settlement of the Cambodia Conflict. (1991). Art 6 Annex 1, UN Doc. S/23177, A/46/608.

Allman, M., Winright, T. (2007). Faith in Public Life: Jus Post Bellum Extending the Just War Theory. New York: Orbis Books.

Cable, J. (1986). The Geneva Conference of 1954 on Indochina. London: The Macmillan Press Ltd.

Chesterman, S. (2004). You, the People: The United Nations, Transitional Administration and StateBuilding. Oxford Scholarship Online. 258.

Doyle, M. W. (1995). UN Peacekeeping in Cambodia: UNTAC's Civil Mandate. Colorado: Lynne Rienner Publishers.

Etcheson, C. (1997). Putting Pol Pot in Jail: Dilemmas of Accountability in Cambodia. American Anthropological Association. 19-23.

Findlay, T. (1995). Cambodia: The Legacy and Lessons of UNTAC. Oxford: Oxford University Press.

Framework Agreement. (1991). Agreement on a Comprehensive Political Settlement of the Cambodia Conflict. Treaty Series No.111. London:HMSO.

Human Rights Watch. (2002). Cambodia: Khmer Rouge Tribunal Must Meet International Standards. Retrieved from https://www.hrw.org/news/2002/12/19/cambodia-khmer-rouge-tribunalmust-meet-international-standards.

Human Rights Watch. (2009). Cambodia: 30 Years After Fall of the Khmer Rouge, Justice still Elusive. Retrieved from https://www.hrw.org/news/2009/01/05/cambodia-30-years-after-fall-khmerrouge-justice-still-elusive.

Keller, L. (2005). UNTAC in Cambodia - From Occupation, Civil War and Genocide to Peace. Max Planck Yearbook of United Nations Law Journal, vol.9. 127-178.

Kiernan, B. (2008). The Pol Pot Regime: Race, Power and Genocide in Cambodia under the Khmer Rouge, 1975-79. New Haven: Yale University Press.

Lambourne, W. (2004). Post-Conflict Peacebuilding: Meeting Human Needs for Justice and Reconciliation. Peace, Conflict and Development. Issue 4. 1742-0601.

Marks, S. (1994). The New Cambodian Constitution: From Civil War to a Fragile Democracy. Colum. Hum. Rts. L. Rev. 26.

Nolte, B. (1995). Unity for Peace. In Wolfrum, Rudiger, United Nations: Law, Policies and Practice. Netherlands: Springer Publisher.

Ojendal, J. (2003). Ten Years of Reconstruction and Reconciliation - What it May Mean in Cambodia. Working Paper Department of Peace and Development Research Goteborg University. No.6.

Ratliff, S. (1999). UN Representation Disputes. California Law Review 87, 1207. 
INTERNATIONAL JOURNAL OF ACADEMIC RESEARCH IN BUSINESS AND SOCIAL SCIENCES

Vol. 8, No. 7, July 2018, E-ISSN: 2222-6990 @ 2018 HRMARS

Ratner, S.R. (1993). The Cambodian Settlement Agreement. AJIL 87.

UN Security Council. (1992). Security Council Resolution 745 (1992) (Cambodia). 28 February 1992. Available at http://www.refworld.org/docid/3b00f1600.html 